\title{
Correction to: Potato Cultivar Susceptibility to Pythium Leak as Influenced by Harvest and Early Storage Temperatures
}

\author{
Andrew K Hollingshead ${ }^{1}$ • Nora L. Olsen ${ }^{1} \cdot$ Mike Thornton $^{2} \cdot$ Jeff S. Miller ${ }^{3} \cdot$ Amy Hui-Mei Lin $^{4}$
}

Published online: 17 June 2020

(C) The Potato Association of America 2020

\section{Correction to: American Journal of Potato Research https://doi.org/10.1007/s12230-020-09769-1}

In the original article there were errors in some of the references. The corrected references follow. There is also an error in the fourth paragraph second sentence of the Introduction. Pyhtophthora should be spelled Phytophthora.

\section{References}

Barr, D.J.S., S.I. Warwick, and N.L. Désaulniers. 1996. Isozyme variation, morphology, and growth response to temperature in Pythium ultimum. Canadian Journal of Botany. 74 (5): 753-761.

Bruin, G.C.A., L.V. Edgington, and B.D. Ripley. 1982. Bioactivity of the fungicide metalaxyl in potato tubers after foliar sprays. Canadian Journal of Plant Pathology 4 (4): 353-356.

Goss, R.W., and J.H. Jensen. 1944. A pythiaceous stem-end rot of potatoes. Phytopathology 34: 1001.

James, R.V., and W.R. Stevenson. 1999. Evaluation of the effect of foliar fungicides on potato storage quality, 1997. Fungicide and Nematicide Tests 54: 180.

Knowles, R.N., and E.S. Plissey. 2008. Maintaining tuber health during harvest, storage, and post-storage handling. Chapter 10. In Potato health management, ed. D.A. Johnson, 2nd ed., 79-99. St. Paul: American Phytopathological Society.

Lévesque, C.A., H. Brouwer, L. Cano, J.P. Hamilton, C. Holt, E. Huitema, S. Raffaele, G.P. Robideau, M. Thines, J. Win, M.M. Zerillo, G.W. Beakes, J.L. Boore, D. Busam, B. Dumas, S. Ferriera, S.I. Fuerstenberg, C.M.M. Gachon, E. Gulin, F. Govers, L. Grenville-Briggs, N. Horner, J. Hostetler, R.H.Y. Jiang, J.

The online version of the original article can be found at https://doi.org/10. 1007/s12230-020-09769-1

Andrew K Hollingshead

akhollingshead@uidaho.edu

1 Kimberly R\&E Center, University of Idaho, 3806 N 3600 E, Kimberly, ID 83341, USA
Johnson, T. Krajaejun, H. Lin, H.J.G. Meijer, B. Moore, P. Morris, V. Phuntmart, D. Puiu, J. Shetty, J.E. Stajich, S. Tripathy, S. Wawra, P. van West, B.R. Whitty, P.M. Coutinho, B. Henrissat, F. Martin, P.D. Thomas, B.M. Tyler, R.P. De Vries, S. Kamoun, M. Yandell, N. Tisserat, and C.R. Buell. 2010. Genome sequence of the necrotrophic plant pathogen Pythium ultimum reveals original pathogenicity mechanisms and effector repertoire. Genome Biology. 11 (7): R73.

Powelson, M.L., and R.C. Rowe. 2008. Managing diseases caused by seedborne and soilborne fungi and fungus-like pathogens. Chapter 19. In Potato health management, ed. D.A. Johnson, 2nd ed., 183-195. St. Paul: American Phytopathological Society.

Salas, B., and G.A. Secor. 2001. Leak. In Compendium of potato diseases, ed. W.R. Stevenson, R. Loria, G.D. Franc, and D.P. Weingartner, 2nd ed., 30-31. St Paul: American Phytopathological Society.

Salas, B., G.A. Secor, R.J. Taylor, and N.C. Gudmestad. 2003. Assessment of resistance of tubers of potato cultivars to Phytophthora erythroseptica and Pythium ultimum. Plant Disease 87 (1): 91-97.

Strand, L. 2006. Integrated pest management for potatoes in the western United States. 2nd ed, 82-83. Oakland: University of California Agriculture and Natural Resources Publication 3316.

Thompson, A.L., R.J. Taylor, J.S. Pasche, R.G. Novy, and N.C. Gudmestad. 2007. Resistance to Phytophthora erythroseptica and Pythium ultimum in a potato clone derived from $S$. berthaultii and S. etuberosum. American Journal of Potato Research 84 (2): 149 160.

Zerillo, M.M., B.N. Adhikari, J.P. Hamilton, C.R. Buell, C.A. Lévesque, and N. Tisserat. 2013. Carbohydrate-active enzymes in Pythium and their role in plant cell wall and storage polysaccharide degradation. PLoS One 8 (9): e 72572.

2 Parma R\&E Center, University of Idaho, 29603 U of I Lane, Parma, ID 83660, USA

3 Miller Research LLC, 426 E 200 N, Rupert, ID 83350, USA

4 Clinical Nutrition Research Center, Singapore Institute for Clinical Sciences, Agency for Science, Research and Technology (A*Star), 30 Medical Drive, Singapore 117609, Singapore 